\title{
At Play in the Space: The concept of 'the social practice approach' in the Scottish adult literacies field
}

\author{
AILEEN ACKLAND
}

\begin{abstract}
This paper focuses on Scotland's policy response to the International Adult Literacy Survey (1994-1998) and the 'grand experiment' (Merrifield 2005) to implement a social practices perspective of literacies. This radical perspective, derived from the New Literacy Studies (NLS), has profound implications for pedagogy and is promoted in Scotland as 'the social practice approach'.

The paper begins with a discussion of the distinctive developments in Scottish policy in the context of the international interest in Adult Literacy. The rhetorical claims made in Scotland are then examined through a study which used a methodology drawn from Personal Construct Theory (PCT) to explore how practitioners understand 'the social practice approach'. This research found little connection between the theoretical concepts of the New Literacy Studies and practitioners' interpretations. Dissonances in the data highlighted power issues between policy and practice. In the latter part of the paper, Bernstein's (2000) ideas about how theoretical knowledge is translated into pedagogical knowledge are used to explore the dissonances further. The paper concludes that there is an ideological conflict of purpose within the discourses of adult literacies in Scotland and that the critical pedagogy implied by the New Literacy Studies is also necessary within teacher education if practice is to be transformed in response to the radical social theory.
\end{abstract}

\section{Introduction - Adult Literacy and Numeracy (ALN) in Scotland in the international context}

Between 1994 and 1998 an international program of literacy surveys was organised by the Organisation for Economic Cooperation and Development (OECD). Overall, more than 20 countries participated in the three cycles $(1994,1996,1998)$ of the program known as the International Adult Literacy Survey (IALS). The aims of the surveys were to provide a comparison of levels of literacy between countries and to contribute to an understanding of the 'demand and supply of skills in the global, knowledgebased economy.' (OECD 2000: iii). The OECD's mission is to influence policy in the direction of economic development and the IALS was explicitly 
intended to inform Lifelong Learning policy in the participating countries. Despite critiques of the survey (e.g. Street 1996), the results received wide publicity, usually as a set of shock statistics in relation to illiteracy and emphasising the deficits to be addressed in a specific country.

In response to the surveys' '... demonstration of the intersection between literacy skills and national economic performance...' and the OECD's claim that '... strategies to build literacy skills .... are pivotal for developing comparative national advantage' (OECD

http://www.oecdbookshop.org/oecd/display.asp?lang=fr\&sfl=DI\&stl $=5 \mathrm{~L}$ MQCR2KBR45) there was a resurgence in governmental interest in Adult Literacy and Numeracy (ALN) in many developed countries.

Consistent with this trend, ALN became a policy priority in Scotland in the decade 2000-2010. Much of the Scottish Government's reaction was similar to that of other European countries and in line with statements from the European Commission (Commission of the European Communities 2001, 2006 and 2007): an investment of funding to provide free and varied opportunities for learning, the targeting of particular groups identified as disadvantaged, a call for raised standards of teaching and learning and the formalisation of the ALN sector for greater accountability (Scottish Executive 2001). Despite such consensus, Scotland has attracted interest from practitioners in other contexts for what has been seen as a less prescriptive government response, and what is now known as 'the social practice approach':

In 2001 the Scottish Executive's Adult Literacy and Numeracy in Scotland (ALNIS) report made 21 recommendations for building a world-class adult literacy and numeracy service for Scotland. This strategy has been internationally celebrated for its learner-centred, social practice approach. (Scottish Government 2010: 6)

Merrifield's assertion that England should 'Look North for inspiration' (2005) met, however, with some concern amongst Scottish academics who cautioned that their situation should not be viewed through 'rose tinted spectacles' (Maclachlan 2006: 32, Ackland 2006, Parkinson 2006) and drew attention to tensions in the Scottish experience.

Critiques of the Scottish situation acknowledged the breadth of the definition of literacy adopted i.e.

The ability to read and write and use numeracy, to handle information, to express ideas and opinions, to make decisions 
and solve problems, as family members, workers, citizens and lifelong learners. (Scottish Executive 2001: 7)

Each were positive about the congruence of this definition with understandings of literacy derived from the New Literacies Studies (NLS) (see for example Street 1984, Gee 2008) and elaborated in particular by the Lancaster school (see for example: Barton 1994, Barton and Hamilton 1998, Barton, Hamilton and Ivanic 2000). The NLS view of literacy as situated, socially constructed and inherently ideological challenges what Street refers to as the autonomous model (Street 1984), which assumes literacy to be a value and context free individual cognitive competence. A social practices perspective, on the other hand, perceives literacies (plural) as multiple, emergent and situated in particular social contexts (Barton et al. 2000). The critiques concentrated on the tensions between these two conflicting models of literacy within Scottish policy. Whilst it was recognised that the language of Scottish policy was distinctive in being informed by NLS, and that the proposed '... lifelong learning approach...' was in contrast to a '... deficit approach...' adopted by other countries '... where the individual is encouraged to take a test that will demonstrate a failure to meet a set standards...' (Scottish Government 2010: 14), critics were wary of the economic drivers behind the rhetoric, and each identified threats to the implementation of the approach in practice. Maclachlan concluded that the social practices discourse in Scotland was 'aspirational' (Maclachlan 2006: $34)$.

By 2008 there had been a widespread adoption of the discourse of 'the social practice approach', yet Hillier (2008) still warned that it was not clear to what extent the social practices perspective of literacies was actually transforming practice. With these doubts in mind, the study presented below aimed to explore how Scottish Adult Learning practitioners' conceptions of practice relate to the theoretical perspective apparently advocated in policy.

\section{The purpose of research with practitioners}

The purpose of the study was to explore how practitioners understand the concept of 'the social practice approach' to adult literacies education. Despite the previously noted concerns about conflicting discourses within policy and doubts about change in practice, by 2008 'the social practice approach' had become an established orthodoxy in Scotland. Talk of 'doing the social practice approach' seemed to be everywhere, unquestioned and unquestionable. Rarely was the approach explained; the assumption seemed to be that everyone knew what it was. However, hearing 'the social practice approach' used as a defence against innovations in practice such as more 
group work, greater use of ICT, participative activities for numeracy teaching, assessment, I began to wonder whether those adopting the term shared the same understanding of its pedagogic implications.

The social practices perspective - primarily a theory of literacies in society - emphasises the inherent power relationships affecting uses of literacies in a social context and illuminates the situated nature of literacies acquisition. Though not a theory of education, it has profound significance for adult literacies work. The assertion of NLS that constructions of literacy are inevitably ideological brings to literacies development work essential questions about what and whose purposes are served by particular literacies. It requires a critical stance which engages not merely with the how of literacies development but more fundamentally the whys. Crowther, Hamilton and Tett highlight this dimension of ALN work in the title of their edited book, Powerful Literacies (2001). They demonstrate in a variety of practice contexts how work with literacies learners requires practitioners to be aware of power relations and to critically examine with learners sociocultural literacies practices. 'A critical pedagogy is required which takes account of the power relationships affecting use of literacies in everyday life' (Hillier 2008: 6). Gee (2008: 45 - 49) provides a very clear illustration of such a critical approach in his examination of the 'aspirin bottle problem'. His analysis of the warning text on an aspirin bottle demonstrates how teaching the 'reading' of such a text must go beyond decoding to engage with questions about drug companies, social relations and the structure of society. Despite the rhetoric of 'the social practice approach' in Scotland, evidence of this aspect of ALN work was sparse (Smith 2005, Tett and Maclaclan 2008). If practice was not changing to reflect this radical understanding of literacy, how were practitioners who claimed to be 'doing the social practice approach' interpreting the meaning of this concept?

As a teacher educator involved in the education of ALN tutors, I was concerned with how the theory of social practices was currently being construed in practice in order that that I may better appreciate the challenge of how the radical theoretical understandings of the NLS could be translated into transformations in practice.

The need for professional development of ALN practitioners is a consistent theme in the discourses surrounding IALS. In this, Scotland was no different from other countries and commitments to provide professional development led to the creation of a new teaching qualification designed to raise standards of teaching and learning in the sector. This Teacher Education program - TQAL ${ }^{\mathrm{i}}$ - was developed and delivered by a consortium of higher and further education institutionsii. A work-based learning program, it brings together practitioners from a range of educational contexts across Scotland. An explicit aim of the program is to 
foster a community of practice in which new understandings of practice can be co-constructed (see Ackland and Wallace 2006). In my role as

Curriculum and Research Leader of the Scottish TQAL Consortium, I had both the opportunity and responsibility to explore with program participants, experienced ALN workers in current practice, changing understandings of the new theoretical perspective.

The research presented here was located in the context of the teacher education program and therefore combined the research aim of enquiring into theories in practice with professional development objectives.

\section{Research Participants}

All participants (75) in the pilot TQAL project of 2008 - 2009 were aware of the research and involved in some way in the generation of and reflection on data. Participants included the program development and teaching team, practice-based student mentors and students on the program. A core group of nine students and two mentors was recruited to contribute to the most intensive dimension of the study, which included structured interviews with individuals.

Students on the TQAL program had a wide variety of backgrounds and practice contexts. Their narratives of how they had come to work in ALN, elicited by an initial autobiographical activity, revealed that none had proceeded intentionally and by a linear route; rather their narratives were marked by serendipity and entrepreneurial responses to changing circumstances e.g.

\section{My choices in the main have been taken for the benefit of my family. Secondly, because I was asked if I wanted to do the jobs/volunteering and each time I could not think of a reason to say no to a new adventure. I have never thought I needed to make sense of the journey! (Extract from a student autobiography)}

These were not paths, but crazy paving, in which individuals often sustained multiple roles and identities simultaneously. Although most had come to ALN 'by way of the proverbial 'backdoor'(Benn 1997: 19), some had previous degrees, either in a vocational subject area or in Community Education. Consistent with Benn's (1997) analysis of the characteristics and influences on adult educators, their varied experiences included vocational education, higher education and community education. Different forms of adult education emanate from different positions on an ideological continuum which includes traditions such as liberal, radical and functional (Benn 1997, Papen 2005); given the patchwork of people's backgrounds it 
seemed likely that their philosophies of practice would 'draw upon many influences and fragments of ideologies'.

Fragments of ideologies or ideas may be absorbed by the educator to create a mental 'mosaic' which may be unsystematic, incoherent and subject to influence. (Benn and Burton 1995, cited in Benn 1997: 21)

The core group of 11 interviewees was selected from the wider group to represent the most common contexts for ALN in Scotland - Further Education colleges, Local Authority community learning services, voluntary organisations - as well as geographic spread. Operating within these contexts it is likely that practitioners' mental mosaics included the different expectations within these settings; the idiosyncrasy of each his/her story, however, pointed to much greater complexity.

\section{Methodology}

Personal Construct Theory (PCT) methodology has been used in a range of contexts for research into the constructs underpinning professional practice (e.g. Day, Pope and Denicolo 1990, Solas 1992, Pope and Denicolo 1993, Hillier 1998). Similar to the notion of mental mosaics, Kelly's (1995) PCT asserts that in reaction to their experience of the world, individuals develop implicit theories which then influence their own responses and behaviours. These implicit theories, ways of making sense of the world, are built from a system of constructs. Construct systems consist of a set of tacit binaries (e.g. happy/sad) against which an individual evaluates the things they experience. According to Kelly, if we can appreciate a person's ways of construing we can begin to understand the meanings they are attaching to things. PCT provides a qualitative methodology and structured techniques to facilitate the exploration of people's interpretations and the ways in which they are constructing, from their experience, models of the world which influence their future behaviours. Denicolo and Pope (2001) describe a variety of ways of exploiting methods derived from PCT to facilitate the transformation of professional practice. Most are based on Kelly's Repertory Grid Technique (Fransella and Bannister 1977) - a method of structured dialogue which aims to elicit the personal construct system underlying a person's response to a specific domain of experience.

These techniques derive from a psychotherapeutic context and thus facilitate a person's exploration of their own construct system. They are therefore a means of engaging professionals in reflective practice through which the tacit is articulated, can be examined and is thus more amenable to change. 
For this research study, methods derived from PCT, and in particular Repertory Grid Technique, were chosen then as a means of surfacing the conceptual constructs tutors held in association with 'the social practice approach'. I hoped to be able to explore their implicit models of teaching and learning in a context in which 'the social practice approach' is the avowed model. Unlike standard research methods, the repertory grid claims to elicit people's ways of construing without influencing them with the researcher's own preconceptions. This was an important consideration given my own place in the research, as TQAL Curriculum Leader and program tutor.

The terminology of Kelly's Personal Construct Theory appears to privilege the individual, yet the theory's assumption about persons is of people in relationship with others (Kalekin-Fishman and Walker 1996: 13): 'For Kelly, people are both fashioned within and fashioned of the complex interpersonal worlds they inhabit.' Although Kelly (1955: 55) asserts that 'persons differ from each other in their construction of events', his theory also encompasses 'commonality' (1955: 90) in ways of construing.

Repertory Grid Technique can be used to explore how people are both similar and different in the way they make meaning of their experiences. In this research I was interested in the extent to which understandings of 'the social practice approach' were similar and different across a group of diverse practitioners.

A fundamental tenet of Kelly's theory is 'constructive alternativism' (1955: 72), that there are always possible alternative interpretations.

Meaning making is an open ended exploratory process in which there is no one truth but 'the search for first causes or final explanations is always in abeyance' (Stronach and MacLure 1997: 26). Carl (1999: 19) explores the intersections between PCT and post modern thought and concludes that:

Postmodernism brings to Kelly an understanding that the construal process of people is highly discursive and powerladen, while Kelly provides a subject-specific and processoriented framework that facilitates a re-working of the modernist subject.

Moreover, these shifts in the way Kelly's theory is regarded reflect my own shifts in the research process - from a focus on the individual understandings of a 'social practice approach' to ALN, to an examination of the similarities and differences in construing amongst a group of practitioners drawn from a variety of professional contexts, to an interest in the discursive and power laden construal process. 


\section{Research Method}

Data was gathered by means of a variety of PCT inspired techniques, some of which were incorporated into teaching and learning activities within the TQAL program. These included: autobiographical writing; a group activity sorting practice-related terminology; an individual writing activity in which students were required to spend 5 minutes writing their own definition of 'the social practice approach'; reflective discussion in the virtual learning environment (VLE).

Central to the study, however, were in-depth repertory grid dialogues with eleven geographically dispersed and differently experienced practitioners. Each repertory grid interview lasted approximately two hours and took place in the work context of the respondent. Each respondent was required to articulate the distinctions they make between different instances - or 'elements' - of practice. In this case, a range of individually relevant elements was generated by means of a generic set of questions designed to elicit details of everyday ALN tutoring practice. The range of elements was therefore unique to each interview. These elements, written onto cards, were then shuffled and presented to the respondent in random triads. In response to each triad, they must explain how they perceive two elements to be similar and the third different.

For example, presented with a triad of elements of adult education practice such as:

\section{USE OF THE INTERNET}

WORKSHEETS

DIALOGUE

the respondent might group them as below:

$$
\text { USE OF THE INTERNET DIALOGUE }
$$

WORKSHEETS

They would then be prompted to articulate how the use of the internet and dialogue are similar, as adult education practice, and how using worksheets differs.

The characteristic shared by two elements becomes one pole of a construct, how the third differs forms the contrasting pole. For example, the construct and its contrast might be

decontextualised / relevant to learners' interests.

By eliciting bipolar constructs, this technique goes beyond what a person affirms about practice and explores the delineating alternatives that they tacitly hold. 
In the course of an interview, random triads are presented until the dialogue seems to have exhausted the variety of main constructs. This is usually evident through increasing repetition. A matrix is then constructed out of the elements and the bipolar constructs that have emerged. Each element is rated from 1-5 on the continuum between the contrasting poles of each construct. These ratings are used to discern the relationships between elements and constructs. In the patterning of elements and constructs, the grid technique attempts to map the personalised meaning each individual is making of concepts of practice.

Each interview generated a unique repertory grid and a recording of the dialogue in which constructs were elicited from the triadic process. The initial grids were subjected to analysis using online Webgrid software (http://tiger.cpsc.ucalgary.ca/), which sorts the grid so that similar elements and similar constructs are clustered together. 'Dendrograms' show the degree to which components of the grid are related to one another, given as a percentage similarity score. The webgrid software also presents the data as a concept map showing the relationship between both elements and constructs in geometric space.

For example, through these instruments, in one instance we were able to begin to see how the practitioner's practice belief in making use of relevant materials in the classroom is linked to an underlying theory that learning should be relevant to the learner's interests and connect to their purpose. Being non-judgmental was also seen to be closely linked, for this practitioner, to the cluster of elements and constructs which they associate with 'the social practice approach'.

At the conclusion of the repertory grid interviews, a variety of representations of the anonymised grid data were shared with research participants for group reflection. This allowed us to consider how interpretations within the group compared.

Data contained in the grids was combined with the breadth of data generated through the various other reflective activities mentioned previously. Extracts of the recorded dialogues were transcribed and the texts of these and the group activities were subject to both micro-linguistic analysis and transcontextual analysis (Rampton 2007); transcontextual analysis looks for traces of official texts - such as curriculum guidelines - in practitioners' reflections.

In the course of the transcription process, as I grappled with the challenge of turning talk into text, I began to experiment with poetic transcription (Lapadat and Lindsay 1999) as a means of being more overt about the process of construction inherent in transcription or indeed any representation of the data. Working with the data in this way foregrounded language and discursive practices. 


\section{Finding Dissonances in the Data}

A number of dissonances emerged in my analyses of the data. Evidence of sameness/generality/conformity jarred with evidence of difference/distinctiveness/othering.

Same?

Terms used frequently in informal discussion in relation to 'the social practice approach' - such as 'learner-centred' and 'relevant' - appeared in some form in each of the grids.

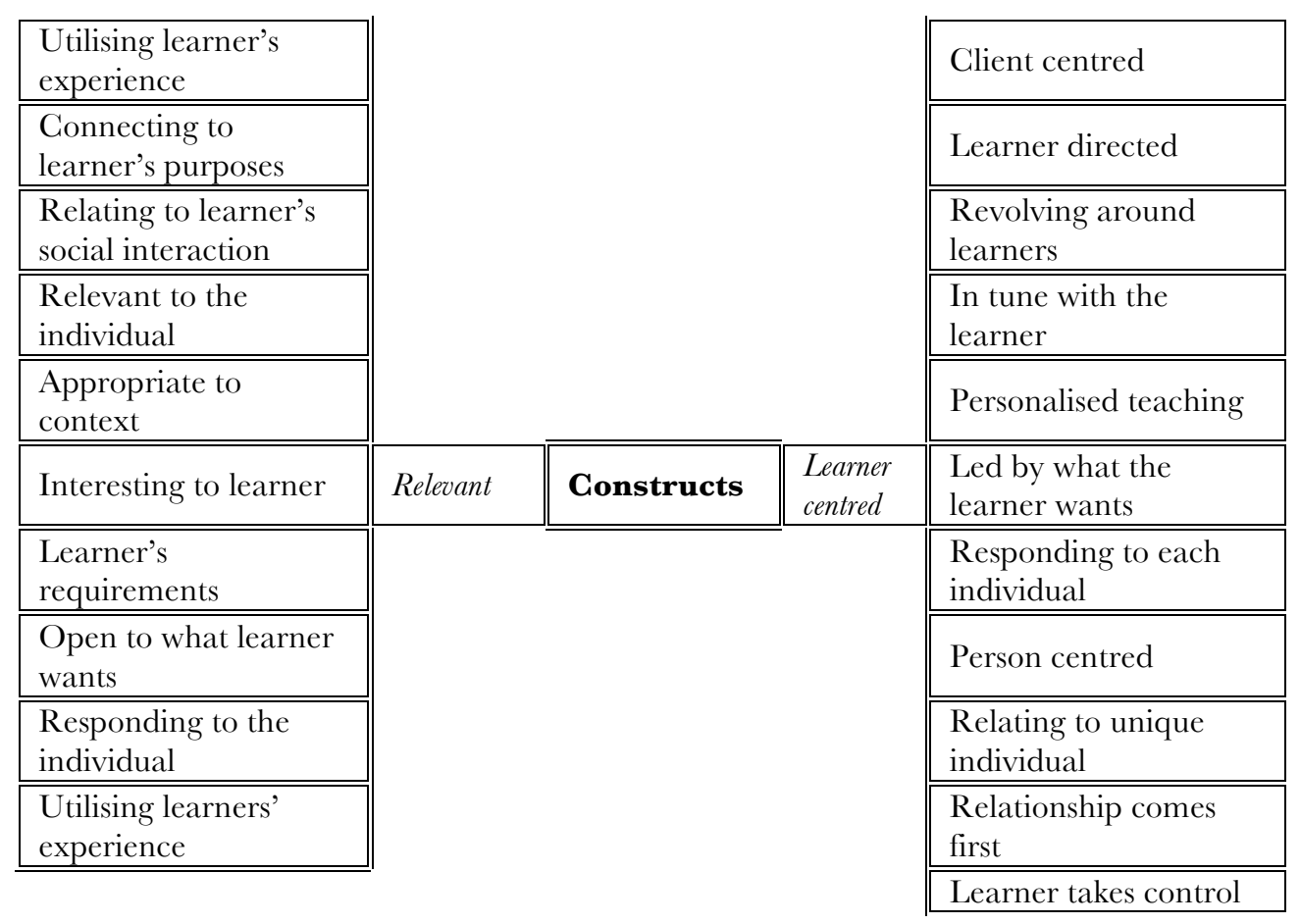

\section{Figure 1: Examples of constructs relating to relevance and learner- centredness}

The program activity in which each student was asked to spend five minutes writing their definition of a social practice approach also generated data in which these terms predominated. For example:

'My understanding of the Social Practice of literacies is that it's directed by the needs of the learner'

'Learner-centred....making the learning process relevant' 
'Creates a relevant link to the learner's life. It individualises learning'

'It's taking the learner's perspective into account and, if appropriate, adapting my practice to their social norms.'

Within this discourse, the learner (singular) tends to be isolated in the learning environment but linked to their individual everyday life, which is unquestioned. The relationship between teacher and learner is generally interpreted as one of service. In the grids, underlying ideas about the need for the tutor to be non-judgemental and non-directive are clustered with notions of relevance and appropriateness.

One participant, reflecting on the collection of grids, was 'unsurprised at the majority of the tables as they fit the current 'preaching' and definitions regarding the Scottish system'. The group's initial reflections on the data concentrated on the apparent conformity. Their reactions to this were mainly negative: 'They are so uniform that they disappoint!' Are we being churned out on a conveyor belt of ALN tutors?'.

\section{Different?}

The grid process elicits bipolar constructs. By paying more attention to the discriminations made by individuals through the contrasts given to the constructs of 'learner-centred' and 'relevant', differences in understandings of these constructs emerged. For example, 'relevant' is contrasted variously with: 'directive', 'treating everybody the same', 'ignoring learners' interests', 'decontextualised'. These contrasts imply different understandings and implications for teaching and learning. Conversely, then, an analysis of the principal componentiii of each grid presented a wide variety in what mattered most to individuals.

\begin{tabular}{|l|}
\hline Principal Component \\
\hline harmony \\
\hline revolving around learners \\
\hline more equal footing \\
\hline relating to unique individual \\
\hline empowering \\
\hline knowledgeable \\
\hline relating to learner's social interaction \\
\hline relationship first \\
\hline energetic \\
\hline reflective \\
\hline broadening \\
\hline
\end{tabular}

Figure 2 - Variation in Principal Components 
A theory that a 'social practice approach' should focus on harmony rather than conflict in the teaching and learning situation and a theory that focuses on empowerment are likely to lead to distinctively different approaches.

The group activity in which students were asked to articulate distinctions between a variety of terms which have been applied to ALN also provided data in which interpretations were confused and contested on the basis of the personal experience of the speaker. The activity used a similar triadic process to the grid interviews. For example, presented with the three terms

\section{ADULT BASIC EDUCATION}

and asked to say how two are different and one similar, the arguments not only drew upon personal experience of different regimes of ALN work but used reference to the authority statements of policy documents. For example, the quote below makes reference to the strategy text albeit based on a partial understanding of its content.

Adult Literacies and functional skills are similar because the ALNIS report drew attention to the importance of functional skills.

In all this data, the criticality implied by the ideological view of the New Literacy Studies is not strongly represented. Where traces of a more critical pedagogical stance do appear they can be linked to aspects of an individual's background influences and thus could be part of their personal mental mosaic. For instance, one tutor who spoke of the importance of connecting learning 'to the bigger picture' had recently completed a social science degree and qualified as a community education professional. In her autobiography she noted her experience of higher education as having been transformative.

\section{General?}

Taken overall, the constructs could be read as representing views of the effective teacher in the particular context of 'the social practice approach'. However, as snapshots of what constitutes an effective teacher, the repertory grid data is very similar to data from contexts which do not espouse a social practices theory of literacies, such as data from the school sector (Hattie 2003) and from other Adult Learning contexts (Battell et al. 2004 (Canada); Hamilton and Hillier 2006 (England), Milana and Larson 2009 (Denmark)). In all of these studies, effective teachers: recognize and respect difference, are sensitive to context, reflective and improvisational. 
As Bernstein (1990: 169) has asserted, 'The most outstanding feature of educational principles and practices is their overwhelming and staggering uniformity independent of the dominant ideology of specific nation states'.

\title{
Distinctive?
}

Despite the similarity with other sources of data, difference is a recurring theme in the transcript data. The practitioners' identity is asserted as different from school teachers and different from English practitioners, who are perceived to use what the practitioners refer to as a 'deficit model': 'the social practice approach' is described as 'flexible', 'not prescriptive... like Skills for Life'w. This claim to distinction through 'othering' (MacLure 2003: 3 ) is discordant with the pervasive sense of feeling obligated to conform to the distinctive Scottish model:

\author{
you say these things because \\ that's the message at the moment \\ its almost that y'know \\ the message \\ that's the party line \\ that's what you've got to do \\ you've got to be on message
}

(Poetic transcription of an extract from a recorded dialogue with repertory grid interviewee 4.)

In the group reflection on the repertory grid data, participants were surprised at the apparent consensus on the characteristics of 'the social practice approach', noting that the tensions they experienced in their varied work contexts in putting this into practice were not reflected in the data. One person, who works in a Further Education college suggested that institutional constraints in her context meant that in reality the Social Practice approach doesn't work'. However, she felt it was not permissible to admit this. There was broad agreement with one interviewee's sentiment that '.. in this day and age you'd get stoned to death if you're not doing the social practice model'.

\section{The 'social practice approach' as discourse}

In these shifts between generality and difference an opening (MacLure 2003: 81) emerged in the data, in which I began to question the discursive practices in the construing of 'the social practice approach'. Initially, I was looking for connections to social practices theory in practitioners' constructs; from this position different ways of construing 
could be perceived as 'treasonable sentiments' (MacLure 2003: 102), betraying a wrong understanding of social practices theory. My reassurances that in the dialogues with practitioners I was not judging as right and wrong versions of 'the social practice approach' were to some extent disingenuous. Certainly the expectation was that I would make such judgements: 'How ultimately are you going to analyse whether a particular person's view of social practices approach is the right one?' (dialogue transcript). In a variety of ways, participants betrayed their anxiety that they would be found out. My powerful position, as the apparent arbiter of meanings could not be wished away. Instead, I began to attend to the power dynamics; to the way in which, in the construing of this thing 'the social practice approach', identity claims (Maclure 2003: 10) were asserted through the division of self and other, and legitimated by reference to authoritative texts.

In the dissonances in the data, I began to view the term 'the social practice approach' as a floating signifier (Foucault 1977 cited in Hjort 2009, 114) detached from what it appears to signify: 'a phrase the most important meaning of which is that it does not mean anything' (Hjort 2009: 114). Free to mean anything, its function is to signal certain positions within a set of power relations. The practitioners' constructions of the term 'the social practice approach', focusing (as shown above) on the relationship with the individual learner and their immediate social context appeared detached from the social practices theory of NLS with its emphasis on criticality. The term was linked to principles of practice which are generalisable across countries and sectors, yet individual interpretations suggested wide variations in the detail of ALN practice. Despite the apparent distinctiveness of the Scottish experience, the practitioners in my study appear similar to the 'eclectic pragmatists' of Hillier and Hamilton's (2006, 116) research in England. Detached from theory, the term was strongly associated with policy and institutional relationships; it was used both to signal conformity to policy expectations e.g. "The social practice approach is about ensuring that all learning that goes on in our service is in line with the Curriculum Framework and embedded in the learner's vocational interests' and to assert professional elitism. Most puzzling, is the sense that practitioners associate both empowerment - 'As an ALN tutor in Scotland I feel I have greater freedom to try new strategies' - and disempowerment with the adoption of 'the social practice approach':

\author{
'there are \\ learnt off \\ rote answers \\ when it comes to
}




the social practice approach
adult learning
the Scottish way
you're not allowed
to think about
whether you
necessarily
agree with it
that's the framework
we work in and
you have to
because it pays your money'

(Poetic transcription of an extract from a recorded dialogue with repertory grid interviewee 10.$)$

Whatever was going on here seemed to be about power and discourse in a space between theory and practice. A space in which the concept of 'the social practice approach' had become detached from its theoretical roots. To understand this better, I turned, then, to a model for analysing the processes by which theoretical knowledge is translated into pedagogical knowledge - Bernstein's (2000) concept of the pedagogic device and, in particular, the recontextualising principle (p. 33).

\section{The recontextualisation of knowledge}

Bernstein's sociology (2000) is concerned with understanding the reproduction of social inequality through education. Initially focussed on language at the micro-level of educational practice, his work ultimately sought to analyse the relationships between micro level discourse and macro level power relations; to explain 'how power relations are transformed into discourse and discourse into power relations' (2000: xxv). Over many years, in which theory evolved in tandem with research, a comprehensive model emerged of the principles which relay ideological interests through educational discourse and generate stability across different systems. In this model, educational reform is understood as an ideological struggle (Bernstein 2000: 66). Bernstein's concept of the pedagogic device provides, then, a framework to examine relationships between theory, policy and practice at a time of educational reform. Hamilton (2001) regards it as useful in her exploration of the development of discourses of literacy flowing from IALS. Ghen and Derewianka (2009) also draw on Bernstein's models 
to explore change in the broad field of literacy education in England, USA and Australia. Both papers are interested in the power relations within the field of literacy education. Drawing particularly on the style of analysis in the latter paper, what follows is an analysis of the Scottish context of ALN which might help to understand the dissonances in my data.

Bernstein's model presents the relationships between theory, policy and practice as those between three distinct fields. Theory is produced in the knowledge production field (KPF) but is then filtered through a recontextualising field. The recontextualising field he divides into two: an official recontextualising field $(\mathrm{ORF})$ and a pedagogic recontextualising field $(\mathrm{PRF})$. This division will be discussed in depth subsequently.

The level of practice is termed the knowledge reproduction field (KRF). It is here that knowledge becomes pedagogy. Of particular interest is the 'recontextualising principle' which describes how discourses are delocated from the knowledge production field and relocated, transformed, in the field of reproduction.

\section{Competing sources of knowledge}

Within the field of knowledge production Bernstein makes a distinction between hierarchical and horizontal knowledge structures. Chen and Derewianka (2009: 225) illustrate that knowledge structures are horizontal in the field of literacy which draws upon a variety of disciplines such as psychology, sociology, linguistics; 'a range of competing theoretical approaches each with its own specialised grammar'. In this horizontal structure, New Literacy Studies, with research methods drawn from anthropology, is a 'new language, a fresh perspective, a set of new connections, and a set of new speakers' (Bernstein 1999 in Chen and Derewianka 2009: 226). Its view of literacy as a set of context contingent social practices is in competition, in particular, with perspectives from psychology which sees literacy as a set of cognitive skills internalised in the individual.

As Chen and Derwianka point out (p. 229) the boundaries between literacy education and special needs education are blurred and the strong psychological base of the latter continues to influence adult literacies education. For example, in Scotland, concurrent with the rhetoric of 'the social practice approach', a medical model of dyslexia prevails; tutors are trained to recognise '... symptoms of dyslexia', which '...cannot be cured'; '...coping strategies and aids may be more useful than literacy teaching...' (Dyslexia Awareness in Adult Literacies Work Trainer's Pack, 2008: 24. http://www.aloscotland.com/alo/viewresource.htm?id=822)

This knowledge with its foundation in psychological research circulates in the field within a set of institutional relations in which dyslexia 
advocacy organisations and experts have powerful influence. There is little attempt to bring it into relation with the different kind of knowledge produced by the New Literacy Studies, which might lead to a critical examination of the ideological purposes of diagnosis.

With respect to ALN in Scotland, then, the knowledge production field is horizontal and a mix of conflicting theoretical approaches. NLS, as a new perspective, is in competition with knowledge from other dominant disciplines such as psychology. The psychological perspective was evident in my data in some practitioners' insistence on the uniqueness of the individual and the requirement to appreciate their distinctive learning styles and needs: 'To me, a social practice view of literacies is recognising the uniqueness of fellow human beings; where they are at and where they want to be.' (Response to program activity in which each student was asked to spend five minutes writing their definition of a social practice approach.)

\section{Hybridity in the recontextualising field}

As has been previously stated, in Bernstein's framework the knowledge recontextualising field is divided into an official recontextualising field (ORF) and a pedagogic recontextualisng field (PRF). The first includes the government and departments of education and the latter, teacher education departments, education researchers, development agencies. Bernstein suggests that the nature of the relationship between the two fields of recontextualisation is key in times of curriculum change (Bernstein, 2000: 115). In Scotland this relationship is complex.

Although policy statements such as the ALNIS report (Scottish Executive 2001) clearly emanate from a government position in the ORF, and the academics - teacher educators and researchers - who have been involved in the Scottish initiative operate mainly in the PRF, other actors within this field are hybrid policy actors (Ball 2008) operating across the ORF and PRF. Learning Connections, the 'development engine' established by the Scottish Executive, is an extreme example. Created in 2003 within Communities Scotland - a government quango - in 2007 it moved into the Directorate of Education and became part of government with responsibility for policy as well as practice development. A review then led to its removal from government to Learning and Teaching Scotland (a non-departmental public body responsible for reviewing curriculum and providing national guidance and advice to the education system) which has since amalgamated with Her Majesty's Inspectorate of Education (HMIE) to form a new agency called Education Scotland. In each of these transformations, Learning Connections' relationship to policy and practice has been a confusion of top down policy implementation and grassroots development and advocacy of practice (Maclachlan 2006: 33). As a central 
actor in the recontextualisation of knowledge its role has been crucial but conflicted.

The hybridity in the discourse of Scottish policy was noted in the introduction. The broad definition of literacy derived from a social practices perspective clashes with a deficit model in which those in need of upskilling are to be identified by 'spotters and referrers' (Scottish Executive 2001: 2) and remediated. The evidence of 'need' is derived from the IALS, which as Hamilton (2001: 183) points out draws on the psycho-metric measurement tradition of psychology. Although common knowledge identifies ALNIS as the point at which 'the social practice approach' took hold in Scotland, the term 'social practice' never appears in the text. The concern addressed by ALNIS is consistent with the concerns of other European countries, in the context of a global education field in which international comparators are strong policy drivers in the competition for national economic success. ALNIS 'sets a goal to exceed world class levels of literacy and numeracy' (p. 1)

In determining the purpose, the WHY of literacies education, the knowledge drawn upon by government is primarily economic. In its discussion of pedagogy, the HOW of literacies education, ALNIS ( Scottish Executive 2001: 27) derives the following list of characteristics 'from consultation with the field [my emphasis]: with

For almost all of the respondents appropriate learning was equated

- learner-centredness

- being aware of the learner's needs and circumstances

- using materials and delivery techniques appropriate to those needs'.

As Hamilton and Hillier demonstrate (2006: 109-124) the notion of learner-centredness has underpinned the rationale of ALN practice in the UK since the 1970s. They describe how this principle evolved out of a number of practicalities of ALN work and draws on a variety of theoretical traditions which pre-date the radical theory of NLS. The 'learner-centred' approach advocated in ALNIS is derived from practice experience. The 'lifelong learning' approach, in which learning is 'relevant to learners lives and goals' is focussed on getting learners through the 'learning gateway' (Scottish Executive 2001: 25); this being seen as the most effective way of getting to the most people who need it and developing their skills. 'The social practice approach' to pedagogy is therefore promoted for its efficacy in meeting policy purposes. It is an approach derived not from the knowledge of literacies produced by NLS, rather from the experience of practitioners who are 'eclectic pragmatists' (Hamilton and Hillier 2006: 116). 
In the ORF, initially then, there is scant use of the knowledge from NLS. Traces, such as the definition of literacy, are recontextualised within the more privileged knowledge and the original knowledge is transformed. For example, whilst a social practices perspective sees literacies as '...complex capabilities...' consisting of '... knowledge, skills and understanding...' (National Development Project 2000), in policy discourse this is reduced to skills and occasionally knowledge, 'understanding', which is connected to the more critical aspects of social practices theory is erased.

Though the term 'the social practice approach' does not appear in the initial policy documents, it is prevalent in texts produced by first the Literacies Development team and then Learning Connections. The 2000 Literacies in the Community (LIC) pack, written by the Literacies Development team refers to 'a social practice perspective', the Curriculum Framework (2006) produced by Learning Connections (crucially in consultation with academics and practitioners), talks of 'a social practice model' and by 2010 the term 'social practice approach' is evident throughout practice facing texts. Within the PRF then, knowledge produced by the NLS is privileged.

Bernstein asserts that, 'It is a matter of some importance to analyse the role of departments of the state in the relations and movements within and between the various contexts and their structuring fields' (Bernstein 1981: 363). My argument is that, oscillating between the ORF and PRF, the hybrid policy actors of the Development team/Learning Connections take to the government remedial project knowledge of NLS. In their developmental role they have worked with key academics, such as Tett (for instance, on the Curriculum Framework, 2006), who are closely associated with the knowledge produced from the NLS. Their position inside government ties them, however, to the government's project and its implementation. In ALIS 2020 (Scottish Government 2010), the refresh of ALNIS, the term 'social practice approach' does appear but as a technology for the more effective implementation of the economy focussed project: 'It [Literacies] is most successfully taught using a "social practice" approach" (2010: 7).

By ALIS 2020, the assumption that the purpose of literacies education is for economic growth is unquestioned. 'The social practice approach' is linked to the quality of 'a world-class adult literacy and numeracy service for Scotland' (ALIS 2020: 6). As Milana and Larson point out in a report which reviews adult education in the European area, 'the term 'quality' mainly seems to refer to the usefulness of different adult education and training offers for the labour market.' (Milana and Larson 2010: 3). 


\section{Cultural diversity in the knowledge reproduction field}

My research explored discourses circulating in what Bernstein delineates as the knowledge reproduction field (KRF). Although the terminology used in practice appears to signify a direct connection to the knowledge produced by the NLS, the conclusion I draw from my research is that the term 'the social practice approach' is used with a variety of meanings and as a defence, justification and demarcation within a context in which the purposes of adult education are contested; it is a floating signifier. As noted earlier (and explored at more length in Ackland 2011), the reproduction field of adult literacies education is characterised by diversity - in terms of contexts, institutional cultures, traditions and practitioner backgrounds and beliefs. These differences are mainly ideological and are distinctions of purpose. Up until very recently an unregulated and fragmented sector, it has been described as 'antitheoretical' (Shaw and Crowther 1995: 206), wary of theory and invested in the pragmatic knowledge of experience. The theorising of literacy within the NLS is both radical and complex, circulating in highly academic texts in a domain and language foreign to most practitioners. Despite the common usage of the language of social practices, it has been our experience as teacher educators within the TQAL project that few practitioners have accessed any of the primary literature of social practices theory. When they do so as part of their studies, they find it difficult to understand and in some cases experience it as deliberately obfuscatory in both language and concept. Consistent with Bernstein's framework, then, the knowledge of literacy produced by the NLS reaches the reproduction field only through the filter of the recontextualising field and mainly through authoritative texts whose authorship is often opaque.

Authoritative texts such as the Literacies in the Community pack, ALNIS and the Curriculum Framework were those most often referred to in my data. Although these texts might be seen as belonging to either the ORF (ALNIS) or the PRF (Lic and Curriculum Framework) they are connected, forming a genre chain (Fairclough 2003: 34) in which discourses are recontextualised and transformed. They are intertextual - each makes reference to the others and seeks to derive its authority from this relationship. The effect is overtly cumulative - an effect which obscures the conflicts both between and within texts. The hybridity of actors within the recontextualising field makes it even more difficult to disentangle one from another, to separate the official project from the pedagogic project.

In this confusion, the critical knowledge of literacies produced by the NLS is emasculated into a technology in the service of a project of neoliberal capitalism. A lifelong learning, learner-centred approach is advocated because it works. As this is recontextualised into "the social practice 
approach' what it works towards remains unquestioned. Although the PRF texts are more explicitly informed by the knowledge of NLS, their intertextuality with the ORF texts reframes this knowledge within the official discourse and its ideological purpose.

I suggest that the dissonances in my data may be indicative of the tensions experienced by practitioners as they are subjected to this confusion of discourse and it is mediated by their own beliefs and values. This notion is further illustrated through exploring two key constructs - learnercentredness and relevance - which had emerged in the data.

\section{'A space in which ideology can play' (Bernstein 2000: 30)}

The constructs of practice that were most prevalent in the research data were learner-centredness and relevance. These echo the directions for 'effective practice' listed in ALNIS. In ALNIS the evidence for the effectiveness of these practices is attributed to consultation with the field. Legitimation is derived from the pragmatic knowledge of practice - not the KPF. Although the elaboration of effective pedagogy in subsequent PRF texts, such as the Curriculum Framework, is more closely aligned with NLS and more explicit in its use of such theoretical knowledge, the practice advocated in ALNIS retains its authority perhaps because it affirms practitioner's own knowledge.

As this knowledge of practice is recontextualised in the PRF literature in the discourse of social practices, practitioners are further validated by the distinctiveness this accords their practice within a broader field of education in which the new knowledge of NLS is not acknowledged. The discourse of 'the social practice approach' is recognised internationally as distinctive; the pride (one might even go so far as to say sense of superiority) evident in my data could be put down to the fact that for many Scottish practitioners they are merely doing what they have always believed is right.

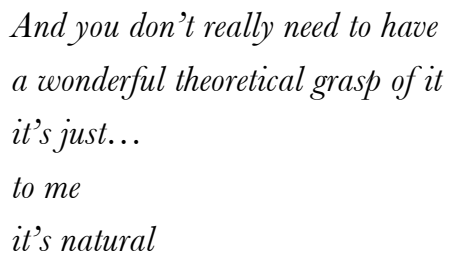

(Poetic transcription of an extract from a recorded dialogue with repertory grid interviewee 5)

However, this alignment between policy and practice is about the HOW of literacies education. In my data, the sense of enforcement was strong. Practitioners seemed to feel obligated to something powerful that 
they distrusted. Their anxieties were betrayed in frequent phrases such as 'churned out', 'stoned to death', 'on message', 'learnt off rote answers'.

Bernstein (2000: 5-15) identifies different types of classification and framing within the process of recontextualisation: in weak classification, subject boundaries may blur and with weak framing, teachers and learners have more control over what is taught. In the recontextualisation field in ALN in Scotland, classification could be considered weak as a broader conception of literacies increasingly blurred the distinctions between literacy, numeracy, ICT and social skills programs. The ALN Curriculum Framework established some key principles but did not delineate what was to be taught, leaving teachers and learners with a great deal of autonomy. Given this apparent flexibility, the sense of coercion in my data is puzzling. Perhaps, however, the sense of obligation is to a purpose, an ideological project which is not their own. The control of the project is not weak, it is strong.

The varied nuances of practitioners' constructions of 'the social practice approach' within the data confirm perhaps the mental mosaics of practitioners in this field. Unexamined, these may be as Benn (quoted above - 1997: 21) suggests, 'subject to influence'. Without an articulated ideology of their purpose as educators, they may be co-opted to others' projects.

\section{Implications for teacher education and curriculum change}

Gee (undated) warned that the language of radical social theories may be recruited to differing political aims; in his view, the New Literacy Studies must include the analysis and use of language to negotiate, advocate and resist the projects of diverse interest groups. I have suggested that in Scotland the language of social practices theory has been recruited to a political aim incongruent with its radical perspective. A social practices perspective of literacies implies a critical pedagogy. If practice in Scotland is genuinely to change in line with this radical theoretical perspective it is imperative that ALN practitioners are conscious of the discursive project and aware of the conflicting projections within it. A critical pedagogy of teacher education is called for in which the curriculum is a form of cultural politics (Giroux and McLaren 1987: 266). Such a curriculum would link 'radical social theory to a set of...practices through which student teachers are able to dismantle and interrogate preferred educational discourses... which have fallen prey to a hegemonic instrumental rationality'(Giroux and McLaren 1987: 278).

Such an approach to teacher education is, I suggest, very different to the strategy for professional development for ALN practitioners advocated by the European Union; a set of key competences has been developed 
(Buiskool 2010) which it is suggested should inform training courses in order to raise the quality of practice. The competences are a list of activities they are exclusively concerned with the how of ALN practice.

We were fortunate, in Scotland, to be developing a teacher education program prior to the emergence of these competences. The research described here was an attempt to follow Gee's advice within the curriculum. The techniques derived from PCT proved to be powerful reflective processes; applied to an analysis of language they facilitated the exploration of the apparently natural in ways which exposed the discursive process of constructions of practice. In illuminating similarities and differences, the research process forced individuals to articulate their own ideologies and encouraged an examination of the ideological nature of ALN practice. As practitioners began to reflect openly on the power relationships in ALN work they engaged anew with critical understandings of literacy:

...we need to keep stretching the boundaries, doing the requirements of the job but always, always broadening this out to include a critical analysis of what we are doing, why and in whose interest - if we don't challenge these and put forward alternative visions then we are not active participants in anything, we are merely deliverers of governmental economic policy and we limit not only what we do but what literacies are! (Extract from a student comment on the VLE)

In this way, it is my hope that the teacher education curriculum moves beyond critique to become one of possibility (Giroux and McLaren 1987: 278), encouraging alternative teaching practices more congruent with the knowledge derived from NLS. If this approach to professional development is sustained, perhaps, in time, Scotland's claim to 'the social practice approach' will be more than aspiration.

\section{References}

Ackland, A, (2006), Lizard Dressed as Lamb? A cautionary reading of the discourse of the Scottish adult literacies initiative, RaPAL, 60, pp 3745.

Ackland, A, (2011) The Eye of the Storm, European Fournal for Research on the Education and Learning of Adults, vol 2, no 1, pp 57 - 73.

Ackland, A and Wallace, D, (2006) Teaching Teaching as Social Practice, paper presented at the NRDC Conference, April 2006.

Ball, SJ, (2008) New Philanthropy, New Networks and New Governance in Education, Political Studies, vol 56, pp 747-765.

Barton, D, (1994), Literacy: An introduction to the ecology of written language, Blackwell, Oxford. 
Barton, D and Hamilton M, (1998) Local Literacies: Reading and writing in one community, Routledge, London.

Barton, D, Hamilton M and Ivanič, R (Eds), (2000) Situated Literacies: Reading and writing in context, Routledge, London.

Battell, E, Gesser, L, Rose, J, Sawyer J and Twiss, D, (2004) Hardwired for Hope: Effective ABE/literacy instructors, Malaspina University-College, Nanaimo BC.

Benn, R, (1997) Adults Count Too: Mathematics for empowerment, NIACE, Leicester.

Bernstein, B, (2000) Pedagogy, Symbolic Control, and Identity: Theory, research, critique, Rowman/Littlefield, Lanham, MD.

Bernstein, B, (1981) Codes, Modalities, and the Process of Cultural Reproduction: A model, Language in Society, 10, 327-363.

Buiskool, BJ, Broek, SD, van Lakerveld, JA, Zarifis,GK, Osborne, M (2010) Key Competences for Adult Learning Professionals, Research voor Beleid, Zoetermeer.

Carl, W J, (1999) Intersections between Kelly's personal construct theory and postmodern thought: How each contests and informs the other, paper presented to Western States Communication Association, February 19-23, in Vancouver, BC.

Chen, H and Derewianka, B (2009), Binaries and Beyond: A Bernsteinian perspective on change in literacy education, Research Papers in Education, vol 24, no 2, pp 223-245.

Commission of the European Communities (2001) Making a European Area of Lifelong Learning a Reality, European Commission, Brussels.

Commission of the European Communities (2006) Communication on Adult Learning - It's never too late to learn!, European Commission, Brussels.

Commission of the European Communities (2007) Action Plan on Adult Learning - It's always a good time to learn, European Commission, Brussels.

Crowther, J, Hamilton, M and Tett, L, (Eds), (2001) Powerful Literacies, NIACE, Leicester.

Day, C, Pope, ML and Denicolo, P, (eds), (1990), Insights into Teachers' Thinking and Practice, Routledge, Hampshire.

Denicolo, P and Pope, ML (2001) Transformative Professional Practice: Personal construct approaches to education and research, Whurr, London.

Fairclough, N, (2003) Analysing Discourse, Routledge, Oxon.

Foucault, M, (1972) The Archaeology of Knowledge, Tavistock, London.

Fransella, F and Bannister, D (1977) A Manual for Repertory Grid Technique, Academic Press Ltd, London.

Gee, JP (2008) Social Linguistics and Literacies: Ideology in discourses, 3rd edition, Routledge, Abingdon.

Gee, J (undated) The new literacy studies and the social turn, accessed by request from http://www.schools.ash.org.au/litweb/page300.html. 
Giroux, H and McLaren, P (1987) Teacher Education as a Counter-public Sphere: Notes Towards a Redefinition, in Popkewitz, T, ed, Critical Studies in Teacher Education: Its folklore, theory and practice, Falmer Press, Sussex, pp 266-297.

Hamilton, M (2001) Privileged Literacies: Policy, Institutional process and the life of the IALS, Language and Education, vol 15, nos 2/3, pp 178196.

Hamilton, M and Hillier, Y (2006) Changing Faces of Adult Literacy, Language and Numeracy: A critical history, Trentham Books, Stoke-on-Trent.

Hattie, J (2003) Teachers Make a Difference: What is the Research Evidence?, Interpretations, vol 36, pp 27-38.

Hillier, Y (1998) Informal Practitioner Theory: Eliciting the Implicit, Studies in the Education of Adults, vol 30, no 1, pp 35-53.

Hillier, Y (2008) Evaluation of the Pilot Programme of the Teaching Qualification Adult Literacies, retrieved 6 June 2013 from http://www.aloscotland.com/alo/viewresource.htm?id=272.

Hjort, K (2009) Competence development in the public sector, in Illeris, K, ed, International Perspectives on Competence Development, Routledge, Oxon, pp 112-124

Kalekin-Fishman, D and Walker, BM (1996) The Construction of Group Realities: Culture, society, and personal construct theory, Krieger, FL.

Kelly, GA (1955) The Psychology of Personal Constructs (vols. 1 and 2), WW Norton, New York.

Lapadat, JC and Lindsay, AC (1999) Transcription in Research and Practice: From standardization of technique to interpretive positionings, Qualitative Inquiry, vol 5, pp 64-86.

Maclachlan, K (2006) Don't Look North Through Rose-tinted Spectacles: Tensions, struggles and guiding lights in Scotland - A reflection. RaPAL, vol 60, pp 32-36.

MacLure, M (2003) Discourse in Educational and Social Research, Open University, Maidenhead, Berkshire.

Merrifield, J (2005) Why England should look North for Inspiration, Reflect, vol 4, pp 20-22.

Milana, M and Larson, A (2009) Becoming Adult Educators in the Nordic-Baltic Region, Danish School of Education, Aarhus University, Copenhagen.

National Development Project - Adult Literacies in Scotland (2000) Literacies in the Community: Resources for practitioners and managers, City of Edinburgh Council, Edinburgh.

OECD and Statistics Canada (2000) Literacy in the Information Age: Final report of the International Adult Literacy Survey, OECD/Statistics Canada, Paris.

Papen, U (2005) Adult Literacy as Social Practice: More than skills, Routledge, London.

Parkinson, D (2006) What's underpinning Scotland's literacies policy?, $R a P A L$, vol 60, pp 28-31. 
Pope, M and Denicolo, P (1993) The Art and Science of Constructivist Research in Teacher Thinking, Teaching and Teacher Education, vol 9, nos 5/6, pp $529-544$.

Rampton, B (2007) Neo-Hymesian Linguistic Ethnography in the United Kingdom, Fournal of Sociolinguistics, vol 11, no 5, pp 584-607.

Scottish Executive (2001) Adult Literacy and Numeracy in Scotland Report.

Scottish Government (2010) Adult Literacies in Scotland (ALIS) 2020: Strategic guidance.

Shaw, M and Crowther, J (1995) Beyond Subversion, in Mayo, M and Thompson, J, Eds, Adult Learning, Critical Intelligence and Social Change, NIAGE, Leicester, pp 204-218

Smith, J (2005) Further Education and the Literacy Debate - A Scottish perspective, Scottish Educational Review, vol 37, no 2, pp 153 -162.

Solas, J (1992) Investigating Teacher and Student Thinking about the Process of Teaching and Learning using Autobiography and Repertory Grid, Review of Educational Research, vol 62, no 2, pp 205225.

Street, B (1984) Literacy in Theory and Practice, Cambridge University Press, Cambridge.

Street, B (1996) Literacy, Economy and Society, Literacy across the curriculum, vol 12, pp 8-15.

Stronach, I, and MacLure, M (1997) Educational Research Undone: The postmodern embrace, Open University Press, Buckingham, England.

Tett, L, Hamilton, M and Hillier, Y (Eds), (2006), Adult Literacy, Language and Numeracy: Practice, policy, research, Open University Press/McGraw Hill, Maidenhead.

Tett, L and Maclachlan, K (2008) Learners, Tutors and Power in Adult Literacies Research in Scotland, International Fournal of Lifelong Education, vol 27, no 6, pp 659-672.

i Teaching Qualification: Adult Literacies

ii The Scottish TQAL Consortium consists of the Universities of Aberdeen, Dundee \& Strathclyde, Cardonald and Forth Valley Further Education Colleges, and two representatives from the field. It is contracted by Scottish Government to develop and deliver the new TQAL qualification.

iiiThe principal components are arrived at by an iterative statistical analysis of variance ie the extent to which the ratings in each row of the grid are similar to each other. At each iteration, the pattern which accounts for the largest amount of variation is identified and removed until all the variability has been accounted for. The principal component represents a key pattern in the grid. (Jancowicz 2004, 127-131)

iv Skills for Life was the name of the national ALN strategy and framework in England at this time. 